\title{
Post-Installation: Insight of coastal-area society in Hybrid Electric Power Systems (HEPS) of Pantai Baru, Yogyakarta
}

\author{
Derajad S. Widhyharto \\ Departement of Sociology, Faculty of Social and Politic Sciences, Universitas Gadjah Mada, Indonesia
}

\begin{abstract}
The Hybrid Electric Power Systems project is a pilot renewable energy project of the Indonesian Ministry of Research and Technology since 2010. Hybrid power (windmill and solar cell) was chosen because of their huge heat and wind potential in coastal area of Pantai Baru. Post-installation is critical, considering the existence of alternative energy was expected to bring changes in the life of coastal people nearby. Participatory Action Research (PAR) was the method used to do deeper exploration of the changes happened after the hybrid electric power installation in Pantai Baru. Coastal society had a bigger dependency on natural resources and secluded from any technology development, including the hybrid power itself. The use of PAR method reversed the top down logic by the Indonesian Ministry of Research and Technology with the bottom up logic, adjust the people's needs which processed from the grassroots. This research was conducted in three years, using three approaches; exploration, reflection, and action. Through these approaches, it was possible for the researchers to understand the actual condition of coastal society and chose the women groups as the main informants as well as the main group which got the biggest benefits of the Hybrid Electric Power Systems (HEPS), they were capable of giving fast responses on the changes happened through the culinary, tourism, fishpond, etc. This condition emphasized both the central role of women and the knot of all dynamics of the HEPS installation. In conclusion, women groups positioned themselves as the transformation agent of the usage of this renewable energy around HEPS Pantai Baru. As the main beneficiaries, women groups had improved their capability to adapt. It increased the income, consumption level, etc. Despite the success of the adaptation, they were still failing their position as the agents and users of the renewable energy. Their existence was limited merely to objects/beneficiaries, instead of being the subjects/actors of the HEPS technology. This study is essential as a data baseline, prepare the policy of technology intervention as well renewable energy campaign.
\end{abstract}

\section{Introduction}

Nowadays, energy is included as one of the main issues discussed in various international agreement. This happened as a form of energy crises anxiety. It is not excessive though when we see the correlation of energy and human being. Human is highly dependent on energy. The process of industrial revolution changed the way people live. Mechanization of all human activities became dominant. Therefore, energy as the main power of human's living tools is absolutely necessary.

So far, the world's energy supplies are dominated by the non-renewable ones. This type of energy come from fossil which produced oil, coals, and natural gas. It needs a long time for a fossil to transform into oil, that is why it is called as non-renewable energy.

The anxiety of the energy crises has emerged throughout the world as there are many estimations said that fossil energy would soon completely decreased. Its high consumption, all for households, industries, military, and others will bring us to the energy crises. The urgency to create renewable energy became clear throughout the world. It was proven when renewable energy became the major issues on several international conferences. In the early June 2004, delegations of 145 states attended the international conference called Renewables 2004 in Bonn, which produced 'Political Declaration' and 'Action Program'. They were previously invited by Gerhard Schroeder in 2002 when German Chancellor delivered a speech at the UN World Summit on Sustainable Development in Johannesburg. The fact that one of the three biggest industry countries took a step in this initiative remarked the renewable energy issues as a part of the world politics.

Optimism in renewable energy emerged in many countries. Those optimism and energy security seemed to be too early. If we take a look at the non-renewable energy (fossil fuel), its consumption rate is relatively increasing. Non-renewable energy consumption is high above the renewable one. In 1990, based on the International Energy Agency, global consumption of fossil fuel ${ }^{1}$ reached 530,000,000 metric $^{2}$ 'ton oil equivalent' (TOE). It reached $8,130,000,000$ ton, there was 44 percent growth in 12 years only. Still, in the same period, renewable energy market segments increased from 1.04 to 1.38 billion metric feet, or 33 percent increased. The consumption gap between fossil fuel and renewable energy growth $4.59-6.74$ billion tons in 12 years.

This continuous growth of energy consumption is a paradox of states' commitments on energy issues. They committed to energy providence, but on the other side, there is the continuous growth of energy consumption each year. Fossil fuel is still considered as the most

\footnotetext{
${ }^{1}$ (crude oil, coal, natural gas)

2 (Metric 'feet' is the international unit of conventional measures for all types of energy);
} 
efficient resources. Differs from renewable energy produced from atom or solar which need advanced technology and high cost. Meanwhile, fossil fuel has a limitation, and it is inevitable. The explanation above matched to Herman Scheer (2007) argument on "Energy Autonomy". Scheer tried to explore various intersections in renewable energy issues. This is important because each day the non-renewable energy start to be diminished. Whilst, renewable energy is still becoming a discourse. This process will bring us into energy disaster if there is no committed action.

Environmental issues previously were the major issues in several conferences and in several countries. Developed countries had planned to develop renewable energy to minimize the environmental damages in the future, such as global warming and greenhouse effect. This concern then encouraged several countries to develop renewable energy usage which eco-friendly and apply eco-friendly lifestyle. Some countries have specific regulations or policies about the renewable energy usage. It emerges the crucial investment, besides the economic investment.

However, renewable energy issues bring out political economy motives. Some parties use the renewable energy concept as an economic investment opportunity which is profit oriented. The coalition between market and government shifted the renewable energy focus. Their actions are not based on environmental and social issues anymore, whereas they focus on making profit for certain parties related to market and government. Renewable energy policies are not that effective. There are always certain purposes during the implementations. The news as well as remarks about it remain as discourses. Market and governments interests play a part here; they are afraid of losing profit when they shift the usage of fossil fuel to renewable ones.

Society development depends on the way it fulfills the needs of energy. Electrical power is the major energy needed by people's daily lives. Therefore, it is basic needs for a production process which affect the economic growth of society. For example, the electricity entry point in a certain area will not solely give them facility in modern agriculture, but also facilitate the modernization of other production processes. The government also give credit to the farmers, by co-operating with some banks which have the branch offices in rural areas.

Indonesia has problems on distributing energy for its people. There is unfair energy distribution in some areas in Indonesia. As an archipelago country, our National Electricity Company or Perusahaan Listrik Negara (PLN) as the main distributor faces challenges in the distribution process. It is making sense to find an alternative way to answer these problems, especially in some remote areas. The Indonesian government is then using renewable energy as one of the solutions.

Through the central government, local government gets the authority to develop renewable energy which expected to be able to fulfill the people's electricity needs. One of the government regulations about renewable energy is Constitution No. 30 Year 2007 about energy. In the verses number 20 and 21 of that constitution written that "(central) government and local government makes effort in provision and management of energy from new sources and renewable energy sources which is addressed corporations, permanent enterprises, and individuals are able to get facilitation and/or incentive from (central) government and local government based on its given authority for certain amount of time until they reached the economic values."

Indonesian Ministry of Research and Technology as the related stakeholder of energy issues had done several types of research about renewable energy in some areas in Indonesia. The coastal area is one of research objects in the early of 2010 because it is one of the hardest areas that PLN need to distribute electricity. One of the areas which used as experiment and research is Pantai Pandansimo Baru. HEPS technology was tried to be installed there because of the similar topography (soil characters). It is also confirmed by the huge wind potential which capable of moving the HEPS turbine.

Moreover, coastal people livelihood and characters are very diverse, such as farmers, merchants, cattlemen, fishermen. The researchers took fishermen as a sample as they constantly lived nearby the coast. Fishermen's lives in Pantai Baru coast, Dusun Ngentak, were not that different from other fishermen's. Even the stereotype about fishermen's habit of wasting money after sailing also happens to them. Fishermen tended to spend their money only in one day to buy things they want at once. They only cared of what they need that day, barely think about the next days and so on. Most of the fishermen in Dusun Ngentak were the lower middle class and still using traditional lifestyle.

Most of them were still having a problem in conserving their seafood. They have to buy ice at the relatively high price and even take long distances to get it. Thus, their profit did not optimally distribute as they take the additional cost for production (fish preservation). Fishermen's lives get worsened by the growth of groceries and fuel prices needed for their job. Uncertain and lowincome got them harder to fulfill their daily needs. Thus, it was too far for them to reach the welfare.

Moreover, in the middle of unpredictable weather and climate as the effect of global warming made them somewhat afraid to go sailing. Bad weather such as huge tide was one of the reasons they choose to stop sailing sometimes. Therefore, they did not get anything for a certain amount of time. Without income, they find it hard to buy fuel. Sometimes, the cost of fuel was higher than their income from sailing. As a survival, particularly in the middle of the unpredictable weather like those days, they had their own strategies to overcome it, such as being farmers, or merchants in the beach area and other things. Coastal people had prepared themselves to become seafood culinary entrepreneurs. However, their efforts sometimes were interfered by lacking electricity, so that their small restaurants only open until the afternoon, they could not make it by night. They were also facing the lack of clean water. Hence, the distribution of electric power 
was a major necessity for Pantai Baru people as the infrastructure to support their development.

The program to conform their needs of energy made to empower them, and it was an innovative idea. As it is known, maritime and fishery development had not shown much significant impact yet. It was proven on how fishermen were still on the edge of poverty. Therefore, it was a good action when government and related Ministry wanted to create alternative solutions and thoughts which meant to empower local people. Thus, they made fundamental changes in the fishermen's perspective, that they might not merely depend on the climate. Fishery management needs to be emphasized on fishermen's selfmanagement. Considering Indonesia as an archipelago country, Indonesia needs more capable people to accommodate all those natural resources as well as responsibly maintain its sustainability. Besides, with that proponent natural potential, people might be able to meet their own needs independently.

After the HEPS technology trial which had been running for five years in the coast of Pantai Baru, people start to see the changes in their lives, both on economic and social aspects. Even, HEPS which is located on the coast of Pantai Pandansimo, Dusun Ngentak, is dubbed as the biggest HEPS in Indonesia. Thus, this research was conducted to know the impact of HEPS installation towards the local people and how far the installation affects the dynamics in Pantai Baru society.

\section{Research Method}

This research was conducted for three years (2012-2014), with the assumption that the duration is effective to the concept of PAR. HEPS was installed on trial in 20102011 so that the two years after that assumed as the postinstallation momentum. Two years could show the adaptation process of society. PAR is orientated to three approaches, exploration, reflective, and action McIntyre, 2008). The first year was the explorative period. Researchers did exploration on the potential and social challenges which are predicted to happen on the field. It began with the actor mapping and even made database about people's lifestyles nearby the HEPS. This was important to map the informants and identify values, norms, social status, and social roles emerged in the field. Considering the trip from campus or researchers' residents to Pantai Baru took about an hour in the morning and 1.5 hours in the evening. Thus, researchers chose to not stay in the location, instead visit the location for an effective week, once a month regularly. In the first year, researchers made some approaches to all of the related stakeholders such as representatives from Ministry of Research and Technology, HEPS managers, workshop, and operators. The result of this first year was actors map, strategic issues, and social lives narrative of local people.

The second year was the reflective year. The approach was changed into reflective to get direct interactive ways between researchers and local people. This action was important to both strengthen and help findings triangulation from the previous year. In this second year, researchers decided to do on-the-spot FGD and in-depth interview to the chosen informants. It was essential as the research was not meant to interfere people's activities, as it was believed there would not any authentic data/answers when we asked them to allocate specific times for the discussion or interview. Hence, we followed their daily activities for a week once a month. There was an assumption that a week was the best period to see the pattern, referred to the sequence days on one week. The result of this second year was transcripts and narratives from many perspectives, problems, and application map of HEPS. In this second year, researchers decided to make coastal women near HEPS Pantai Baru as the main informants.

From the second year, the development of HEPS had already mapped and inflicted environmental effects around it. Several affected parties in Dusun Ngentak were the fishermen group and merchants group. Both of the group were affected directly and mostly because of their locations were nearest to the HEPS construction area.

Another party affected by HEPS construction was people who work as farmers and cattlemen. HEPS construction did not bring impact as big as it is to them brought to people who domiciled and did economy activities in the coastal area. The least affected group of HEPS installation was the people who were not included as merchants, fishermen, farmers, and cattlemen. People worked as civil workers, employees, or factory labors and others did not get any direct impact of the HEPS.

The third year, it had reached the action phase. Research process had already found the map of issues, problems, and HEPS utility relations. Thus, persuading people to do actions towards both the issues and their lives as coastal people is the next goal this year. In this third year, it was also prepared a workshop for women group of Pantai Baru coast to encourage them to think about renewable energy in their surroundings. This workshop was held in their houses or shops. Even, women group were also asked to do a comparative study tour to another place which was relevant for the development of their entrepreneurship and the utilization of renewable energy as the focus. The result was a map of the entrepreneurship development opportunities as the utilization of the renewable energy of HEPS Pantai Baru.

Those activities in the third year showed that HEPS had an impact on the society, including the women of Dusun Ngentak who are the main focus of this research. Women of Dusun Ngentak experienced all changes, from the HEPS pre-installation whereas they were still focused on domestic sector then after its installation in Pantai Baru they moved forward to the public sector.

Generally, not all data in the research used in this article. The writer tried to use several data thought to be relevant to the issues about the post-installation impacts.

According to researchers, there were some weaknesses of using PAR as a method, such as 1) it was not easy to build trust with informants in a relatively short time, considering the condition where researchers did not stay in the location every day, 2) from the people's point of 
view, this method could represent grassroots voices, but this method could not reach the higher level to change or affect the policy-making process at the same time, 3) This method needed sufficient time to do data identification and extraction, as researchers relied on the limited numbers of field notes, transcripts, interview records. Hence, researchers and team consolidated the data after we finished the interviews to rewrite on the log book and reckoned on our memories from the last interviews we did on the field with the informants.

\section{Literature Reviews}

Feenberg (2002), in the preface of his book "Technology and Transformation : From Marxian to Radical Critique" emerged the argument of Harry Braverman that the Capital concept of Marx is not a single concept. According to Braverman, there are two major critics of capitalism which related to one another. Feenberg specifically divided it into two conceptions, namely property theory and labor process theory. While property theory related to the economy analytical process, labor process theory is associated with the sociological process as the main base.

Labor process theory defined the way of capitalist organized the workers or labor as deskilling or abolishment of their authority in creating something. Its relevance to technology, the usage of the machine as replacement of men power enables them to decline the numbers of workers. Thus, in this context, besides their loss of authority, workers also lose their creativity as they played the role of machine operators. The usage of the machine or deskilling will indeed cut the cost of wages they should pay significantly. In the other side, this will also influence the political process in the society where deskilling used as capitalist's hegemony basis, both in the work environment and society in general.

The people's ignorance and inability in understanding this production process in the system, making them the easy object of capitalist hegemony. All this time, workers thought that the knowledge they had in the specific area is their subjective rationality as a human. In fact, production mechanism changes their subjective knowledge as an object of authority, wherein the end subordination is not something to be enforced anymore, instead, it is known as a consequence of technology usage.

"A new"law"of economic life has arisen with the new technology, a law that commands"fitness of the laborer for varied work, consequently the greatest possible development of his varied aptitudes."However, by its very nature capitalism requires just the opposite, an ignorant and docile labor force tied to highly specialized tasks. This is the" absolute contradiction between the technical necessities of Modern Industry, and the social character inherent in its capitalistic form" (Marx, 1906:1, 533-534 in Feenberg, 2002).

The statement above tell us that the use of technology upon the men power had reversed the logical thoughts of the industry. If previously, there is a belief that right persons for the right jobs, capitalists have reversed it with people who are the foolest and obedient as the most favored person with skills needed for the jobs. It is exactly differed and contradicted to the technical necessity of modern industry as well as the social characters relevant to any forms of capitalism.

Talk about the relevance of technology, Marx could be said unable to explain the relations between the work process and technology. Marx still thought that to reach socialism, the production force needs to be separated from the capitalist production relations. This perception never talks about the position of technology in his way to separate production force from the mechanism of the production process. George Lucas in Feenberg (2002) said that Marx's perception was not technology determinism. He assumed technology and work relations as production mode.

Besides, Marx was seen as ambiguous in explaining the position of technology in his conception of capitalism critics. This ambiguity can be influenced by his effort to reject romanticism about technology instrumental values which would overtake him. Hence, Marx finally limits his critic about technology merely on the abuse of machine. He also wrote that people who reject those rational reasons as fools because they did not fight against capitalist but merely fight against the machine as themselves. In a scrutiny which not only focuses on negative influences, critics would be spread to the whole aspects of machine and technology. Thus, people who fight against or criticize technology without knowing the limit would be ignorant, as a person, he will not be able to detach himself from any form of technology.

Variance or separations of "workers and technology" as itself, in fact not simply discharge Marx from critics. Since there is no "technology as itself " because technology comes up or only exist when there is reasonable context to support its existence. In another word, there will be no machine or technology if there is no job to finish. That is why technology relevant to the function of "use" . Even Feenberg argues that the usage of word "machine" become ambiguous. Since, the usage of this machine word can be directed to any form of technology used by people, whether in the context of capitalization or not.

Based on Marx, usage of technology is considered as bad when it determined into these indicators : 1) the actual purposes they want to achieve by using technology. 2) how is the technology used apart from its purposes, 3) technical principles in the production process will influence in forming technology, as well as the duration of work hour, work atmosphere, and other problems related to work safety.

In this article, technology is not assumed as a neutral entity and accessible for everyone. It is a thing needed to be learned through education and rational planning. While the access to education is not available for everyone, thus, the capitalist's attraction to technology involving its design, innovation, choices, and usage method. Although it is never be written, Marx critics to capitalize actually 
offend technology either. Whereas, based on the design of this critic, capitalist technology actually was formed and influenced by other capital aspects, such as management as the controller.

In the end, critics to technology rise as a part of the technology development which cannot be separated from interests, where social power upon people's necessity is one of the reasons why technology exist. Since then, this article perceives technology as the dependent entity, instead of a dependent variable to the social system, as a purpose which is formed by the dominant class, as well as a subject from the creating effort of new hegemony in society.

\subsection{Technological Rationality}

Marcuse's technological rationality theory in Feenberg (2002) was influenced formally as formal rationality is less dependent on values. In his theory, Weber argued that rationalization will clearly prosper the capitalists. It is inevitable that the control over technology, whether it is in the past or now is the major source of power. Marcuse argued in his technological rationality theory that technology does not care about people. Technological rationality is the tools to control people. The control is not solely to the individuals and the equipment but either to the individual's freedom itself. Marcuse argued more that where there are production activities, there must be domination towards the individuals. Domination might occur through the managerial system or work division system so that it will be more efficient. Domination system occurs so that workers will never take control of the company. This concept is similar to the alienation concept by Marx, but its domination is not revealed through regulations, however, unconsciously is internalized by workers.

\subsection{Power/Knowledge}

This article also uses Foucault's statement which quoted by Feenberg (2002) as a correction to Marcuse's theory which is somewhat bias. Foucault also believed that power and domination have openly done. Social control which had applied by Foucault is more about control of time efficiency to achieve discipline. Foucault believed that technology is not value-free, there is partiality towards capitalists. Truth and power are not separable, where there is power, there will be the truth. For example, leaders are always right. Foucault said research about human would not be certainly influenced by the situation. Human's cognitive and social power are similar to Marcuse's duality about enforcing rationality which using vehicle assembly as an example. Foucault argued that control/knowledge is power to dominate individuals as both subjects or objects.

The subject here is defined as individuals as themselves, whilst object is defined as individuals with others, such as technology or else. The system used here is not enforcing, but in the other way can make individuals obey rules automatically. Technology is one of the tools to rule individuals. When there is trouble to individuals, it will be assumed to be technical trouble and not enforcement. Later this thing is structured, and when there is trouble, the capitalists see how the workers fix it.

\subsection{Technological Configuration}

While the green revolution was taking place (1960-1970), stakeholders in this case government expected new varieties in agricultural products, particularly staple food. The expectation emerged because the fundamental perception of Green Revolution is increasing agricultural products through some following steps : provide the irrigation system, optimize chemical fertilizer, usage of pesticide, and usage of quality seeds. Although, mechanization of agricultural area is included in the agricultural modernization process. It is not the only one; there is still any other technology such as pesticide, fertilizer, etc.

The green revolution and agricultural modernization, farmers, are demanded to speed up their production process. So that, after the harvest season, farmers need to get the area fertilized and ready for planting. One of the essential instruments in the agricultural process is a tractor. Farmers who have tractors will successfully improve their lives, with following indicators : enhancement of clothing, meals, houses, and recreations. This encourages other farmers who do not have a tractor yet to buy ones, let alone the market offers various kind of agricultural equipment.

Furthermore, technology existence is potentially rising socio-economical stratification. People who used to have social integration become have dysfunction, for example, farm labor who do not own any field loss their job because technology replaces their position, encourage them to move to the urban area and occupy workforce in informal sectors.

Based on the explanations above, some of the research findings by M.J. Campbell (1989) shown that impact of technology in several countries, particularly in their rural areas create significant changes, below.

\subsubsection{Changes in family roles}

The family who had experienced mechanization in the process of harvesting process spend less time in the field because the process is faster compared to a family who has not go through mechanization process.

\subsubsection{Impact on children growth}

Before the modernization and technology, children in rural areas are expected to contribute in domestic sectors in their early ages : get water, deliver food, etc. Nowadays, the family tends to realize the importance of education for children, both boys and girls. 


\subsubsection{Impact on labors}

Some perceptions about the impact of agricultural mechanization in rural areas are increasing numbers of employee and worsening of poverty. Yet, data indicates that there is some misunderstanding in the perception about labors. It happens because of several following factors.

a. Although modernization and mechanization had already happened, the necessity of labors in agriculture is not declining. Farm labors are still needed for planting and weeding process, as its harvest and planting period are much faster.

b. There are transportation facilitation and infrastructure which enable unemployees to find jobs in other places.

c. The government of rural areas provide new vacancies, at least in short period of time, and provides vacancies for untrained or semi-trained workers.

\subsubsection{Changes in works and skills}

Agricultural mechanization encourages villagers to understand the equipment they need to use. At least they know the maintenance procedures and simple reparation. This knowledge will lead the farmer family has skills to operate the tractor in a safe way. Furthermore, this process will be used as learning process by one of the family members who have specialization in one certain thing, such as tractor reparations, irrigation tools replacement.

\subsubsection{Relations between family and society}

Agricultural mechanization and the life improvement increase public services as well as people's expectations. The residential standard has enhanced, demands on water and electricity have become primary needs of each family. The entrance of private sector in a rural area has changed rural people's perspective; then they started to become more independent to fulfill their own facilities that government cannot provide. Families who have capital has increased their influence in rural society. Then, their capital becomes social modal to decide the policies in the rural area.

\subsubsection{Relations to the other market sector}

The entrance of private sectors in rural areas formed new markets. Some dominant areas in this new market forming process are:

Savings and loans institutions, both government or privately owned ones.

a. Sales and services institutions of agricultural machines.

b. Political and religious institutions.

c. Entertainment provider institutions for rural people, social services, and health clinics.

\subsubsection{Mobility of Families}

The mobility of families, whether it is traditional or the ones who already mechanized expand their perspective about the world they have never seen before. As people meet the world, they have experience interacting with new societies. It positively impacts the way they see their rural area and lead them to be more open to changes. While the negative side is they tend to break their cultural norms they used to obey all this time.

\subsubsection{Changes in aspirations and expectations}

The family which is experiencing mechanization has widened necessity compared to the one who is still traditional. There is an anxiety in modernized rural people that they might not be able to meet their needs. It is not based on intuitive reasoning. Instead, it comes from their past experiences. People's needs that used to be simply made for survival has enhanced into - mostly fulfillment of life improvement facilities, such as further education access up to university. People's expectation of life can be divided into four categories : 1) high standard of life : electricity and water, 2) proper houses : houses which build properly, 3) better infrastructures and 4) recreations for people.

\subsubsection{Changes in family economy}

The improvement of the economic base among rural people is the impact of their great expectation towards the facilities they want. Even, to fulfill their needs, there is a tendency to take the loan as a way to increase their capital or improve their economic base.

In the end, critics to technology rise as a part of technology development itself which cannot be separated from interests. Social power upon people's needs become one of the determinants the creating of technology. This article considers technology, not as independent elements, instead one of the variables dependent on the social system, a purpose which formed by dominant class, as well as subject from the creation process of the new hegemony in the society.

Evolution occurs in the technology cannot be seen as an autonom process, yet have to be associated with interests and social groups.

This approach saw the labor division and technical conception are unable to compare to the development of workers' capacity individually. Because they who are part of the worker class never put interest in technology because their discussions are still questioning welfare. It proves the argument of Feenberg (2002) at the beginning of this literature review that there is an incompatibility between what workers want and the reality had done by capitalists in the field. The production process is designed to be a control system by the dominant class rather than fulfillment mechanism of the worker's rights. In this Pantai Baru HEPS case, coastal women played a part as the workers of technology. 


\section{Research Findings}

In response to the Pantai Baru HEPS construction, here are some actors who earn benefits from the HEPS construction, one of them is a group of women. Women are quite vulnerable to changes around them, particularly their domestic situation at homes as well as the environment. When there is new element come in (read: HEPS), it will give major influences to women condition, such as her job and income. After the installation of HEPS, women which are previously identified to be solely in domestic sectors, finally come to the public sector (Amirrudin, 2012).

Women's issue in the economy is not far from poverty (Anggraeni, 2010). Therefore, giving them the opportunity to participate in economic activities and other more chances are the right way, whereas women can work outside of their homes, contributed to their families' income.

Women's role in the informal economy sector is one of the significant roles in upgrading their status in the social structure of Dusun Ngentak. Here is following socio-economical changes emerged post-installation of Pantai Baru HEPS.

\subsection{Fishery Group}

This group is found since there was a program of fishery ponds construction nearby the location of the Hybrid Electric Power Systems (HEPS) initiated by the Ministry of Maritime and Fishery. The formation of this fishery group was initially made as women empowerment activities in Dusun Ngentak. Fishery ponds were then being managed by women of Dusun Ngentak which members of the fishery group called Kincir Mina Mulya Group.

Another purpose of its establishment was making use of empty land around the windmills, and making it as new side projects for the women of Dusun Ngentak to get additional income. In the management process, the Ministry of Maritime and Fishery did a workshop to improve people's knowledge about the benefits and fishery management system. That workshop was held for women (mothers) of Dusun Ngentak which belong to Kincir Mina Mulya Group. The workshop was held like direct socialization about "how to be lucky fish farmer". Lucky here was meant to be a fish farmer who can manage the fingerlings well so that they would get the best result as well. In the process, Ministry of Maritime and Fishery gave them initial capital aid, namely fingerlings and fish feed. Furthermore, they also held training session (practical training) and comparative studies to get more potentials and knowledge about fishery management in the coast of Pantai Baru.

HEPS installation in the coast of Pantai Baru had been the main livelihood for the existence of fishery group Kincir Mina Mulya. The fish ponds relied on the electric power produced by the HEPS. The energy was used to move the water pumps so that the water will flow to the fish ponds. Meanwhile, the ownership status of the ponds based on the ownership of the land. Thus, in the managerial operations of the fishery pond groups, they responsibly manage all the things such as maintenance and profits together.

In the process, when the harvest time came, not suddenly all the farmers of Kincir Mina Mulya successfully got profits. Some of them were failed. It happened when the farmers could not maintain their ponds well. There were found some of the ponds unmaintained so that they were unable to produce fishes continuously. There were some abandoned ponds and were not optimally used. Otherwise, the farmers who could make use of the fish ponds as their economic potentials. They could take benefits from the Ministry's aid so that they got profits of it.

The good intention from the Ministry of Maritime and Fishery, to actualize the women empowerment program in Dusun Ngentak, through the establishment of fishery ponds in Pantai Baru coast also got both pro and contra reactions from people.

"Yes, just like the realization of these ponds constructions, when all the tools and materials to construct them were totally afforded by the government the people's sense of belonging to those ponds must be less than what we expected. Automatically, their responsibility is weak either, because they didn't contribute any capital. So that, we see many failures in the first year. It because the fishery farmers' low sense of belonging to maintain and do the fish breeding." (citizen of Dusun Ngentak)

According to pro groups and people who have positive responses to this program, saw these ponds construction by Ministry of Maritime and Fishery as benefits. Since those ponds could be used as their second job which took not much of their time but gave them additional income for their daily needs. However, there were dissents, particularly people who gave a negative reaction, one of them was Jaman ${ }^{3}$ (50 years old), one of the fish merchants in the tourism spot of Pandansimo Baru. He said his disagreement to the installation of HEPS.

According to Jaman, the HEPS installation process in the coast of Pantai Baru was not initialized with proper socialization to people. So that, in the process, not all of the people could accept it. For example, construction of fishponds, that program was dubbed as a waste of money. That program seemed to be unsustainable. Whereas, it was planned to be not merely as additional income, but also support the lives of less productive fishermen when they were not able to sail. Yet, to Jaman, those fishponds did not successfully solve the lack of fish stocks.

Besides, another thing which tribulates fishery farmer's struggle was the feed supplies. Fingerlings and fish feeder from the Ministry of Maritime and Fishery only came for once at the beginning of the program. Thus, farmers need to feed the fishes by themselves to keep the fishponds sustainable, maximized the initial capital aid from the ministry. The price of factory-made feeder for fish was really high so that it became a burden to them. Meanwhile, high production cost discouraged many of them to leave this kind of activities as they thought it was not prospective anymore. In the end, the ponds left abandoned.

${ }^{3}$ Interview 11.03.2012, 10.30 a.m. 
Therefore, it is necessary to find the alternative fish feeder which is affordable and have the same nutrition as the one which made by the factory. One of them is maybe reproduced worms in $1 \times 1$ meters in a medium containing cow's waste and worms so that it is hoped their problem on fish feeder issues will be solved.

\subsection{Agricultural Group}

Geographically, although it is located on the coast of Pantai Baru, Dusun Ngentak areas were dominated by fertile agricultural land. Thus, most of the people there work as farmers. It frequently used as their main activity for a living. However, the high production cost and unpredictable climate change often lead them to failure. The failures made the farmers suffer a big loss. According to them, not having any profit from the harvest meant they would not have any meals to eat. Thus, it was necessary to find an alternative way for them to pay their loss after the crop failures, at least to afford their daily needs. While waiting for the harvest time which could take a long time, they could do other things to earn money. Anything, as long as they could fulfill their needs which were not slightly simple.

At the beginning of the HEPS installation in Dusun Ngentak, farmers were one of the groups who reacted negatively toward the plan. HEPS construction certainly needs time and much land in the process. So that, it was necessary to give wide spare land for the HEPS. This condition was seen as a threat to farmers. A Certain amount of agricultural land was converted for the sake of the HEPS installation. However, most of the land used by farmers was part of the Sultan Ground, which meant it all belonged to the Sultan of Yogyakarta, and they were afraid and upset when they asked them to give it back to the Sultan. It happened because the land conversion from agricultural land into HEPS area (although not all of the land) was not only involved them as the farmer but also related to their families' lives.

Nevertheless, as time went by, through some effective and prevalent approaches as well as socialization, people finally accepted the HEPS installation in a positive way. As Mujiyo, the Leader of Farmers Group4 said people then realized and accepted the decision to install HEPS in Pantai Baru coast. It is not merely because the land was part of Sultan Ground, they then believed that HEPS would make a change and give benefits in their lives continuously.

The hopes were finally answered. People of Dusun Ngentak, particularly the farmers, got to benefit from the HEPS installation; they could cut the production cost. It happened because of the irrigation system. Before the HEPS existed, farmers needed 60,000 IDR to irrigate their fields. It was already covered the fuel cost, solar and diesel which they needed to rent for. While after the installation they only needed 10,000 IDR. HEPS had a crucial role in the irrigation system in Dusun Ngentak farming area. Farmers could use the electric power to operate the pumps to water their lands.
Despite the domination of men in agricultural works, the women of Dusun Ngentak also actively participated. It could be seen as the women regularly helped their husbands in the field, from the seed planting until the harvest time. Although the men still dominated the process, women's active participation in agricultural activities helped farmers to press the production cost and accelerate the process of seed planting, so that they did not need to wait for harvest time any longer.

\subsection{Culinary Group}

After the installation of HEPS in Pantai Baru, trading became the new favorite livelihood of Dusun Ngentak people, especially the women. They began to sell seafood; seafood culinary entrepreneurship was the new most favorite job for the women there. The opportunity was taken by women who previously sell snacks in front of their homes and housewives. The emergence of these culinary entrepreneurs began after the HEPS. HEPS became a magnet which attracts people to visit Pantai Baru. The tourist enthusiasm encouraged people of Dusun Ngentak to finally process the seafood they got from their fisherman husbands. Culinary entrepreneurship was expected to add the family's income. So far, there were at least 80 (eighty) families listed as a member of culinary entrepreneur groups in Pantai Baru coast.

The culinary entrepreneurship phenomenon in the coast of Pantai Baru which was dominated by women proved that women could exist and contribute in public sector. For example, Suharyati (25), one of the culinary entrepreneurs, said that before she joined the culinary entrepreneur's group, she was only active in the domestic sector and only helped to look after their cattle. Since she became a culinary entrepreneur, Suharyati found a way to express her skills and interest in culinary, as well as help her family's economic condition.

Although the location which was used for the culinary outlets was not their private lands, the merchants did not get any charge or paid rent cost for it. But, they had to pay 1,000 IDR per week to the leader of the culinary entrepreneur's group, Jamali. It was used as the cost for their own developments, such as training for seafood processing innovation. The culinary outlet construction was a part of the economic development program of HEPS installation. Based on its size, the outlets divided into several types. The first type (I) is the biggest one and has the biggest size, namely $12 \times 25 \mathrm{~m}$. The second type (II) is $6 \times 9 \mathrm{~m}$, and the third type (III) is $5 \times 6 \mathrm{~m}$. The people who could occupy the outlets and do economy activities there was only the people of Dusun Ngentak, the outsiders were not allowed. It was because the ones who could take direct benefits from the HEPS were the nearby people first. It was also expected that women empowerment could be implemented as it planned before.

The benefits of HEPS post-installation for the women of Dusun Ngentak, especially who worked in culinary were described below. 


\subsubsection{Crystal ice}

Crystal ice production became prominent for the culinary entrepreneurs post-HEPS-installation. It was easier than for them to get consumable ice. The distance between the ice producer, HEPS, and the outlets is quiet adjacent and made it easier for the entrepreneurs. On the other hand, the price was really affordable and boosted the sustainability of this business. It made the entrepreneurs enable to cut their production cost to the price of the ice so that they got more profits. One big box of ice is 10,000 IDR. If they bought it as retail, it cost 1,000 IDR. Meanwhile, they used to buy ice far from HEPS for 2,000 IDR.

\subsubsection{Electricity}

The outlets got electricity from the HEPS. Although it was relatively small (the electric current), it had helped many outlets there. On the weekend and on holidays like Saturday and Sunday, the activities are going on until the evening, depending on the visitors. They were not only used for restaurants, but the outlets were also used for social meetings and activities, such as prayers, sports activities, or many other things until the evening. The HEPS takes an essential role in the business.

Nonetheless, the entrepreneurs of Pantai Baru were still expecting for the development of HEPS. It was because they hoped that HEPS could provide greater energy, not only to street lightings but also for other necessities. As Anis (41 years old), one of the entrepreneurs of Pantai Baru, she hoped that HEPS would be able to provide electricity for her cooking equipment such as rice cooker, magic jar, blender, and so on so that she could serve her customers faster.

\subsubsection{Tourism Group}

Post-installation of HEPS in the coast of Pantai Baru emerged several new work groups in Dusun Ngentak society. As it explained before, there were some groups emerged after the installation of HEPS such as fishery, agriculture, and culinary groups. As an addition, they also had the tourism group who emerged as the great tourists' enthusiasm to visit Pantai Baru post-HEPS-installation. HEPS was tourism attraction so that it made Pantai Baru became more well-known. HEPS made Pantai Baru as a beach with an educational message, named as a technology-based tourism spot. The HEPS windmills of Pantai Baru were developed as Techno Park and became an edutourism icon on the coast of Pantai Baru (Widhyharto, 2015).

Tourism group was born as the HEPS developed involving clothing merchants, public toilet keepers, ATV renters, kids pool renters, and parkingmen. Previously, tourism group of Pandansimo Baru already existed, but not many people interested in it. It was shown on the small number of visitors in Pantai Pandansimo Baru. After the HEPS windmills installed, the tourists were growing each day.
Yanti (29 years old) as one of the clothing merchants in Pantai Baru said that before the HEPS installed, Pantai Baru was deserted so that there were no economic activities around the beach. Yanti was only a housewife before; then she could help her family's economy by being clothing merchants in Pantai Pandansimo Baru area. Previously, she was culinary entrepreneurs, but to her selling clothes was more prospective compared to culinary. According to her, HEPS took important roles in opening business opportunity as well as its sustainability. Before HEPS exist, there was no activity in the evening, even in the afternoon, the beach looked so quiet. Thus, after HEPS was installed, Pantai Baru became alive and could help people for a living. ${ }^{6}$

Lastri (29 years old) also felt the benefits from the HEPS installation in Pandansimo Baru coast. Lastri worked as public toilet keeper after the HEPS installed, said that she felt the positive change in the economic growth of Dusun Ngentak people. In a half day, Lastri could earn 70,000 IDR. Tourism group of Pantai Baru which also involving the ATV and kids pool renting, was completed by many tourism facilities for the visitors. It helped them to improve the beach's tourism attraction because the location which was near to HEPS. ${ }^{7}$

\subsubsection{Women on Post Installation}

Post HEPS installation in the coast of Pantai Baru, had made a great social change in the women economic condition of Dusun Ngentak, Bantul, Yogyakarta. In conformable to the first plan of the HEPS installation, which was to empower women. Women of Dusun Ngentak had been given the opportunity to contribute in economical aspect. The chances were proven on the emergence of business groups which take a chance after the HEPS installation, such as fishery, agriculture, culinary, and tourism groups. In each sector, women had an active role in developing those sectors.

Culinary, for example, most of this sector was overtaken by women. Women had space to express their skills and interests in processing foods. Women were the main target of this culinary development program, considering their cooking skills, the culinary sector was dubbed as their new arena to express women existences in public sectors. Easy access to get the main as well as the complementary ingredients to be processed as delicious seafood were one of the good reasons to develop this business. The seafood culinary business was supported by its strategic location which was on the coast. Women could directly help their husbands to sell their seafood through served them into delicious dishes.

So did the women who worked in the fishery sector. Using the opportunity to be fishery farmers, women who diligently work on it could get profits and continuously breed the fishes. Although, sometimes they experienced failures, and suffered great loss. So that, it came the Indonesian proverb, "besar pasak daripada tiang" or in

\footnotetext{
${ }^{6}$ Interview, 11.03.2012, 12.30 p.m.

${ }^{7}$ Interview, 11.04.2012, 15.30 p.m.
} 
English "bigger pole than the peg", meant there was unbalanced budgeting lead to the greater production cost than the profit, at least they could take lessons from each experience. Step by step they would be able to measure the market potential to get profit. Women of Dusun Ngentak had the courage to try and learn. Yet, not all of them get the great profit, at least through this fishery business they could decline their boredom of household routine. It was also helped them to fulfill their daily needs. At least, through this two sectors, we could see the existence of HEPS in Dusun Ngentak had to impact in making changes of women's social and economic condition. The emergence of new business groups after the installation was the prove. Although it only provided a small amount of power.

Before the installation, most of the women of Dusun Ngentak were housewives which only active in domestic sectors only. Being wives and mothers is the usual daily role of those women. Husbands were the only one who worked for a living and fulfills the family needs. That explained why they lived in a barely sufficient condition. Although, not all of them, most of the women of Dusun Ngentak felt less productive if they were only active in the domestic sector and only helped their husbands sometimes if it is necessary.

Nonetheless, since they became more independent, ran their own businesses, women helped husbands to do economic activities for their families. When they were working, women could earn additional income, so that she could manage their household income to make some saves for the future. Actually, those four factors could be done by one woman to be followed by other women. It was because there was easy access, provided allowance/subsidy for the initial capital, strategic location, followed by business opportunities. But, the limited space made not all of the women get the opportunities (Widhyharto, 2014).

HEPS installation and the tourism development in Pantai Baru not only implicated in the women economic growth. The tourism development impacted the social lives of Dusun Ngentak women. The development of economy tourism system, the women groups, began to rise as a way to organized women who worked in the tourism sector in social activities, such as monthly "arisan" (regular social gathering). That activity meant to strengthen their social relations as the same economy actors.

The social harmony had formed by the group activity could support women's business/economy sustainability in Dusun Ngentak. Social connections which had been formed among the women can be social capital for them to develop better tourism in the future.

\section{Conclusion}

Basically, the HEPS installation had the two main purposes which also interconnected to each other. First, HEPS has the main task to guarantee the local needs of energy. In this case, hybrid energy was used as the electric power provider for people of Dusun Ngentak. Electricity was a technical aspect, in this case how it could be distributed to people to fulfill their needs on electricity. Second, the HEPS was expected to improve the economic condition of people nearby, through the usage of electricity as the support facilities of their economic activities and people empowerment in Dusun Ngentak.

By chasing the two purposes, the hybrid energy existence can intactly be innovative products which bring benefits to people. Thus, the role of hybrid energy will be able to reach the fair energy distribution for all layers and elements of people. In the case of women of Dusun Ngentak, we can see several opposite sides related to the changes in the process of energy distribution.

The dynamic of the changes in women of Dusun Ngentak can be seen in two phases, pre and post installation of HEPS. Before the installation, women were only active in the domestic sector, where women were busy with their household routine activities and worked in subsistent agriculture. They were positioned as the second actor in the social structure of Dusun Ngentak. Men domination was really powerful in all sectors, especially public sector which holds common interests. Men were the real actor who got the responsibility for the lives of family and society. While, women stayed to household activities such as babysitting children, cooking, or helping their husbands in the agriculture or looking after their cattle.

Women of Dusun Ngentak indirectly experienced injustice and limitation which occurred culturally. The perception which saw women as weak and placed them in the domestic sector was the form of the unfair social system. Consequently, a woman could not be a free and independent person, because the injustice which constructed socially led them to feel inferior. The social system which ran culturally was a sign that choices in the dominant or public sector would be fully managed men, although actually, women have the equal power to manage. Roles and status of women became unrespectable when they were in the public sector. In consequence, men will overpower the strategic sectors and involve the technology determination.

Since the development of Pantai Baru region, supported by the HEPS installation, there were many changes involved the role and status of women in public sector. Women who used to be dubbed as weak and incapable of doing things on public sectors, nowadays experiencing a paradigm shift. The development of Pantai Baru and installation of HEPS opened spaces for new activities to women so that they could express their capabilities and skills. Generally, electricity provision program and people economy development in Dusun Ngentak had given impact in upgrading women social status in society as well as their economic condition.

Women's position in public sector, particularly in the development process of Pantai Baru as tourism area had a significant change. Women have a great role in maintaining the tourism activities in Pantai Baru. Economy activities which were developed as a 
supplement in beach tourism had diffused into varied sectors, such as culinary entrepreneurs, souvenir merchants, even some jobs like keepers of a public toilet and playground rides. Activities which were dominated by women, soon be the major livelihood. The incomes earned helped the family economy, even so, they became the main income for their families.

Women of Dusun Ngentak did not only take part in culinary and tourism business. Actually, there were many other sectors where they participated and occupy the strategic positions. For example in the fishery, fishery development program lead women to take a strategic position as the main actors because it was targeted to empower women of Dusun Ngentak. Unfortunately, it did not work optimally because they could not operate it well. Only small numbers of people who can take benefit from it.

In general, women of Dusun Ngentak more concerned to develop culinary business and trading because they think those were more prospective and directly connected to the tourism sector of Pantai Baru. Culinary business and trading were the sectors which were handled by all women of Dusun Ngentak. The management was diverse, it could be self-managed as a family business, or was managed by a group of mothers who did not have the capital to start a business by themselves. So that, almost all of women in Dusun Ngentak involved in the culinary business and trading activities in Pantai Baru.

The condition was reversed compared to the one before the HEPS installation and tourism development. Women who were previously treated as the second actor, then become a central actor in the tourism development as well as their family economy. Since, without women's participation in Dusun Ngentak, tourism in Pantai Baru would never be developed until now. Women of Dusun Ngentak started to lift up their lives and found the balance in managing public sectors of Dusun Ngentak

Furthermore, the HEPS gave a chance for women to the wide access and was supported by their culinary businesses or trading activities. Although not all of the businesses in Pantai Baru used electricity power from HEPS, the even researcher found that in early 2016 some outlets had used electricity from the national electricity company (PLN). It happened because HEPS could not provide sufficient energy for the developing tourism necessity.

Although women were not directly involved in the installation process and management of hybrid technology in Pantai Baru, and the domestic sector was still women's main realm, at least there were changes in role and status of women. Their position became more respectable, and they have a prominent role in the technology and tourism development in Dusun Ngentak. This position emphasized that women as actors of renewable energy usage. They had the capability to do self-improvement through the usage of limited hybrid energy, then capable of upgrading their positions in the social structure of Dusun Ngentak.
Thank you for Amirrudin, Vicky Dian, and Fauzia Hisyam for contributing in the discussions and data submissions at the fieldwork.

\section{References}

[1] Amiruddin, et.al, 2012, "Menuju Keadilan Dan Kedaulatan Energi Terbarukan: PLTH sebagai Eskalator Transformasi Kehidupan Sosial Ekonomi Perempuan di Dusun Ngentak, Desa Poncosari, Kecamatan Srandakan, Kabupaten Bantul, Yogyakarta (Toward Justice and Renewable Energy Sovereignty: HEPS as the Escalator of Women's Social-Economic Transformation in Ngentak Poncosari, Srandakan, Bantul, Yogyakarta)". Report of Hibah Bina Desa, LPPM UGM. (in Bahasa Indonesia)

[2] Anggraeni Liestya et.al, 2010, "Pembangkit Listrik Tenaga Hibrid (PLTH) sebagai Penggerak Transformasi Sosial dan Kesejahteraan Komunitas Nelayan Pesisir Pantai Pandansimo, Dusun Ngentak, Desa Poncosari, Srandakan, Bantul, Yogyakarta (the Hybrid Electric Power Systems (HEPS) as the Social and Welfare Transformation Booster of Fishermen Community in the Coast of Pantai Pandansimo, Ngentak, Poncosari, Srandakan, Bantul, Yogyakarta)", Research Report of Hibah Mahasiswa, Departemen Sosiologi, Fisipol UGM. (in Bahasa Indonesia)

[3] Campbell, M.J, 1989, New Technology and Rural Development: The Social Impact, Routledge, London.

[4] Feenberg A, 2002, Transforming Technology: from Marxian to radical critique, Oxford University Press, New York.

[5] McIntyre A, 2008, Participation Action Research, Sage Publication, London.

[6] Scheer, Hermann, 2007, Energy Autonomy: The Economic, Social and Technological Case for Renewable Energy, Earthscan Publication.

[7] Widhyharto, D.S, et al., 2014, Penguatan SosialEkonomi Kelompok Perempuan Pesisir: Konsep dan Praktik Pemanfaatan PLTH Pantai Baru, Yogyakarta (Social-Economical Strengthen Strategy of Coastal Women Groups in the Concept and Practice of the Usage of HEPS Pantai Baru), Departemen Sosiologi, Fisipol, UGM. (in Bahasa Indonesia)

[8] Widhyharto, D.S, 2015, "Perempuan Sebagai Agen Perubahan Sosial-Ekonomi Masyarakat Pesisir Sekitar PLTH, Kab.Bantul, DIY (Women as Agent of Social-Economical Changes of Coastal Society of HEPS installation area in Bantul, DIY)". Indonesian Journal of Community Engagement, Vol.1, No.1, Page156-171. (in Bahasa Indonesia) 